УДК 664.665

\title{
THE INFLUENCE OF STRUCTURE FORMING FOOD ADDITIVES ON THE QUALITY OF GLUTEN-FREE BREAD MADE FROM THE MIXTURE OF RICE AND CORN FLOUR
}

\author{
V. Drobot, L. Mykhonik, A. Gryschenko \\ National University of Food Technologies
}

\begin{tabular}{|c|c|}
\hline Key words: & ABSTRACT \\
\hline $\begin{array}{l}\text { Celiac disease } \\
\text { Gluten-free bread } \\
\text { Recipe compositions } \\
\text { Rice flour } \\
\text { Corn flour } \\
\text { Hydrocolloids } \\
\text { Bread quality }\end{array}$ & \multirow{3}{*}{$\begin{array}{l}\text { It is necessary to use structure forming food additives to } \\
\text { ensure the viscous-plastic properties of the dough and its } \\
\text { gas-holding ability in the technology of gluten-free bread. } \\
\text { The article is devoted to the study of the influence of xan- } \\
\text { than gum, carboxymethylcellulose (CMC) and hydroxypro- } \\
\text { pylmethylcellulose (HPMC) on the quality of gluten-free } \\
\text { bread from a mixture of rice and corn flour. According to } \\
\text { the results of laboratory baking of gluten-free bread, it is } \\
\text { established, that the best quality of the products by loaf } \\
\text { volume, surface of the bread and porosity structure is pro- } \\
\text { vided by adding a mixture of xanthan gum and HPMC in a } \\
\text { ratio of } 0.5: 1 \text { when adding } 1.0 \ldots 1.5 \% \text { to the flour mass. }\end{array}$} \\
\hline $\begin{array}{l}\quad \text { Article history: } \\
\text { Received } 08.11 .2017 \\
\text { Received in revised form } \\
22.11 .2017 \\
\text { Accepted } 13.12 .2017\end{array}$ & \\
\hline $\begin{array}{l}\text { Corresponding author: } \\
\text { V. Drobot } \\
\text { E-mail: } \\
\text { npnuht@ukr.net }\end{array}$ & \\
\hline
\end{tabular}

DOI: $10.24263 / 2225-2924-2017-23-6-21$

\section{ВПЛИВ СТРУКТУРОУТВОРЮВАЧІВ}

НА ЯКІСТЬ БЕЗГЛЮТЕНОВОГО ХЛІБА

\section{ІЗ СУМІШ РИСОВОГО ТА КУКУРУДЗЯНОГО БОРОШНА}

\author{
В.І. Дробот, Л.А. Михонік, А.М. Грищенко \\ Національний університет харчових технологій
}

Використання добавок структуроутворювальної дї в технології безглютенового хліба обумовлено необхідністю забезпечення в'язко-пластичних властивостей тіста та його газоутримувальної здатності. Стаття присвячена дослідженню впливу камеді ксантану, карбоксиметилцелюлози (КМЦ) та гідроксипропілметилцелюлози (ГПМЦ) на показники якості безглютенового хліба з суміші рисового та кукурудзяного борошна. За результатами пробних лабораторних випікань безглютенового хліба встановлено, щзо найкраша якість виробів за об'ємом, станом поверхні та структурою пористості забезпечується додаванням суміші камеді ксантану та ГПМЦу співвідношенні 0,5:1 за дозування 1,0-1,5\% до маси борошна.

Ключові слова: целіакія, безглютеновий хліб, рецептурні композицї, рисове борочно, кукурудзяне борочно, гідроколоїди, якість хліба. 
Постановка проблеми та аналіз останніх досліджень і публікацій. Поряд 3 традиційними хлібобулочними виробами, в Україні поширюється виробництво хлібобулочних виробів цілеспрямованої функціональної дії, в тому числі і дієтичних, що рекомендовані для споживання людям з певним видом захворювання. До таких виробів відносять безглютенові вироби, які призначені хворим на целіакію.

Целіакія - це патологічний стан, при якому у кишечнику хворого не розщеплюється та не засвоюється білок глютен, що міститься в деяких злаках (пшениця, жито, ячмінь, тритікале). При цьому в кишечнику накопичуються токсини, які ушкоджують клітини слизової оболонки. Для лікування цього захворювання і профілактики ускладнень необхідне дотримання безглютенової дієти $[1 ; 2]$.

Варто зазначити, що споживачами продукції «Gluten free» $є$ не тільки хворі на целіакію, а й люди, які не мають цієї хвороби. Сьогодні в мережі Internet створено безліч сайтів 3 кулінарними рецептами для приготування безглютенових страв, в тому числі хлібних і кондитерських виробів. Безглютенова дієта стає популярною навіть серед людей, які не хворіють на целіакію. Деякі дієтологи стверджують, що надлишок глютену в організмі погіршує роботу кишечника і засвоєння макро- та мікронутрієнтів, тому обмеження споживання глютеновмісних продуктів сприяє загальному оздоровленню організму, запобігає розвитку деяких хвороб [3-5]. У науковій літературі зустрічаються різні думки 3 цього питання, вивчення його продовжується, проте чисельність прихильників безглютенових продуктів харчування постійно зростає. В Україні сегмент ринку цих продуктів недостатньо розвинений $\mathrm{i}$ представлений, в основному, імпортною продукцією, яка має досить високу вартість.

Оскільки хлібні вироби належать до основних продуктів харчування, необхідно постійно розширювати їх асортимент, задовольняючи потреби населення в оздоровчих і дієтичних виробах. Розробкою технології безглютенового хліба займаються в Україні та за кордоном. Вчені Харківського національного технічного університету сільського господарства імені Петра Василенка запропонували виробництво безглютенових бездріжджових хлібних виробів 3 кукурудзяного та рисового борошна у співвідношенні від 50:50 до 30:70 відповідно, з використанням для розпушення тіста гідрокарбонату натрію та інтенсивної механічної обробки [6]. Також у цій установі розроблена технологія хлібобулочних виробів на основі безглютенових борошняних сумішей 3 використанням як структуроутворювачів колагеновмісних білків і фермента трансглютамінази [7]. За результатами досліджень, проведених у науководослідному Інституті продовольчих ресурсів, встановлено, що фермент трансглютаміназа також забезпечує якість виробів з високими споживчими властивостями у разі сумісного використання з сухим яєчним альбуміном, або сухою молочною сироваткою [8].

У Національному університеті харчових технологій розроблено та затверджено рецептури безглютенового хліба, до складу яких включено кукурудзяний і картопляний крохмалі, рисове, гречане і кукурудзяне борошно, добавки структуроутворювальної дії (камеді гуару і ксантану). Встановлено, що 
борошно круп'яних культур доцільно вносити в кількості $20-30 \%$ замість маси крохмалю. Збільшення дозування борошна призводить до різкого зменшення об'єму виробів і погіршення стану м'якушки [9].

Для виготовлення безглютенових хлібних виробів дозволяється використовувати продукти переробки таких культур, як рис, гречка, кукурудза, пшоно, сорго, амарант. У невеликих кількостях використовують продукти переробки бобових (сої, гороху, квасолі, люпину) та олійних (соняшнику, льону, кунжуту, ріпаку) культур, а також горіхову сировину [1]. Як правило, в рецептури виробів включають кукурудзяний, картопляний, рисовий, тапіоковий крохмалі або їх суміші. Кількість крохмалю в рецептурі становить в межах $50 \ldots 90 \%$ від маси сипкої сировини, що дає змогу отримати хліб більш «легким», 3 кращим об'ємом та структурою пористості м'якушки, але значно знижує його харчову цінність. Оскільки вищезазначені види сировини, на відміну від пшеничного борошна, не містять білків клейковини, в тісто додають структуроутворювачі (різноманітні гідроколоїди): камеді рослинного і мікробного походження, пектин, желатин, агар-агар, альгінати, модифіковану целюлозу (КМЦ і ГПМЦ), карагегани, $\beta$-глюкан тощо. Ці речовини підвищують в'язкість тіста, завдяки чому підвищується його газоутримувальна здатність [10]. У рецептурах виробів може бути використана одна речовина або декілька у різному співвідношенні, що по-різному впливають на якість готової продукції. Якість виробів також залежить від складу крохмалевмісної, білоквмісної сировини, наявності цукру, жиру тощо.

Вченими досліджено вплив альгінату натрію, натрій-КМЦ, модифікованого крохмалю, пектину цитрусового, камедей ксантану і гуару на якість безбілкового хліба. Встановлено, що найкращі органолептичні та фізико-хімічні показники у зразків хліба $з$ додаванням 0,5\% камеді ксантану до маси крохмалю [11]. Високу якість мають вироби 3 сумішей безглютенового борошна та крохмалів із сумісним використанням камеді ксантану і похідних целюлози [8].

Дані, наведені в праці [12], показують, що додавання 2\% пектину, 1\% карбоксиметилцеллюлози та $1 \% \beta$-глюканів покращує якість безглютенового хліба на основі рисового борошна, кукурудзяного крохмалю і казеїнату натрію за показником пористості, та подовжує тривалість збереження ним свіжості.

Науковці Афінського національного технічного університету [10] вивчали вплив ГПМЦ, камеді ксантану, к-каррагенану та гуарової камеді на реологічні характеристики тіста та показники якості хліба з суміші кукурудзяного крохмалю та рисового борошна. Добавки-гідроколоїди додавали в кількості $1 \%, 1,5 \%$ та $2 \%$ і встановили, що за органолептичними показниками найкращу якість мають вироби 3 додаванням 1,5\% ГПМЦ.

Слід зазначити, що наведені вище результати досліджень проводили 3 рецептурними композиціями для виробництва безглютенового хліба на основі сумішей зі значним вмістом крохмалю (більше 50 \% від маси сипкої сировини). Даних щодо використання структуроутворювачів та їх комбінацій для виробництва хліба з круп'яного борошна без додання крохмалю обмаль.

Для досліджень нами було обрано рисове та кукурудзяне борошно, які найчастіше використовують у технології безглютенового хліба. За хімічним 
складом ці види борошна доповнюють один одного і при сумісному використанні дають змогу отримувати вироби зі збалансованим вітамінним i мінеральним складом.

Метою дослідження є вивчення впливу КМЦ і ГПМЦ на показники якості безглютенового хліба з суміші рисового та кукурудзяного борошна; визначення оптимального дозування цих структуроутворювачів та їх комбінацій для забезпечення високих споживчих властивостей виробів за об'ємом, станом поверхні і м'якушки.

Матеріали і методи. Матеріали дослідження - рецептурні композиції для приготування безглютенового хліба з суміші рисового і кукурудзяного борошна 3 різними структуроутворювачами; тісто та хліб, виготовлені 3 вищезазначеної сировини.

Методи досліджень - органолептичні, хімічні, фізико-хімічні, загальноприйняті і спеціальні, виконані з використанням сучасних приладів та інформаційних технологій.

Результати і обговорення. Для обгрунтування складу борошняної основи та визначення кращого рецептурного складу на початку досліджень вивчали органолептичні показники безглютенового хліба. Випікали хліб з кукурудзяного, рисового борошна, а також з їх суміші у співвідношенні 50:50 без додавання крохмалю. Додавали 0,5\% камеді ксантану до маси борошна для забезпечення в'язкості тіста та його газоутримувальної здатності. Було встановлено, що всі зразки незначно відрізняються за питомим об'ємом, який становив для хліба 3 кукурудзяного борошна - $185 \mathrm{~cm}^{3} / 100$ г, 3 рисового борошна $192 \mathrm{~cm}^{3} / 100$ г, 3 суміші - $190 \mathrm{~cm}^{3} / \Gamma$. Всі зразки мали нерівномірну пористість, 3 рисового борошна - товстостінну, 3 кукурудзяного та 3 суміші - тонкостінну. При розжовуванні хліб з кукурудзяного борошна мав жорстку, а хліб 3 рисового - липку м'якушку. 3 суміші цих видів борошна м'якушка була більш еластична і не липка. Смак хліба з суміші також був більш приємним, не відчувалось яскраво вираженого присмаку рисового або кукурудзяного борошна, характерного для виробів, виготовлених лише 3 одного 3 цих видів борошна.

Отже, за базову борошняну основу для приготування безглютенового хліба нами було обрано суміш рисового та кукурудзяного борошна у співвідношенні 50:50 з додаванням дріжджів пресованих, солі, цукру, олії соняшникової та структуроутворювачів — камеді ксантану, КМЦ, ГПМЦ та їх комбінацій. Гідроколоїди вносили в кількості $0,5 \ldots 1,0 \%$ до маси борошна. Дозування обирали згідно з рекомендаціями виробників добавок і даними, наведеними в літературі. Тісто готували безопарним способом без бродіння, поділяли на заготовки, розкладали їх у форми і проводили остаточне вистоювання за температури $37 \pm 2^{\circ} \mathrm{C}$ до готовності та випікали за температури $210-220^{\circ} \mathrm{C}$.

Дані таблиці показують, що вироби з доданням похідних целюлози мають кращий об’єм, але гірший стан поверхні, ніж вироби 3 камеддю ксантану. Збільшення дозування гідроколоїдів, за винятком камеді ксантану, призводить до зростання об'єму виробів і показника пористості. Додавання ксантану більше $0,5 \%$ до маси борошна не тільки зменшує об'єм, а й ущільнює м'якушку, пористість стає нерівномірною й товстостінною. Вироби з ГПМЦ 
характеризуються значно більшим об'ємом та дрібною, рівномірною, тонкостінною структурою пористості, але, як і вироби з КМЦ, мають пласку поверхню 3 тріщинами.

Таблиия. Показники якості безглютенового хліба із суміші рисового та кукурудзяного борошна

\begin{tabular}{|c|c|c|c|c|c|c|c|c|c|}
\hline \multirow{3}{*}{ Показник } & \multicolumn{9}{|c|}{ Внесено добавок, \% до маси борошна } \\
\hline & \multicolumn{3}{|c|}{ Камедь ксантану } & \multicolumn{3}{|c|}{ КМЦ } & \multicolumn{3}{|c|}{ ГПМЦ } \\
\hline & 0,5 & \begin{tabular}{|l|l}
0,75 \\
\end{tabular} & 1,0 & 0,5 & 0,75 & 1,0 & 0,5 & 0,75 & 1,0 \\
\hline $\begin{array}{l}\text { Питомий } \\
\text { об'єм, } \\
\mathrm{cm}^{3} / 100 \text { г }\end{array}$ & 190 & 185 & 170 & 195 & 209 & 220 & 210 & 237 & 265 \\
\hline $\begin{array}{c}\text { Пористість, } \\
\text { \% } \\
\end{array}$ & 61 & 57 & 48 & 62 & 63 & 64 & 63 & 65 & 68 \\
\hline $\begin{array}{c}\text { Колір } \\
\text { скоринки }\end{array}$ & \multicolumn{3}{|c|}{ Жовто-коричневий } & \multicolumn{3}{|c|}{ Жовтий } & \multicolumn{3}{|c|}{ Світло-жовтий } \\
\hline $\begin{array}{c}\text { Стан } \\
\text { поверхні }\end{array}$ & \multicolumn{3}{|c|}{ Гладка, без тріщин } & \multicolumn{3}{|c|}{$\begin{array}{c}\text { Нерівна, пласка, } \\
\text { з крупними тріщинами } \\
\text { на поверхні }\end{array}$} & \multicolumn{3}{|c|}{$\begin{array}{c}\text { Нерівна, пласка, } \\
\text { з дрібними тріщинами } \\
\text { на поверхні }\end{array}$} \\
\hline $\begin{array}{c}\text { Колір } \\
\text { м'якушки } \\
\end{array}$ & \multicolumn{9}{|c|}{ Кремово-жовтий } \\
\hline $\begin{array}{c}\text { Структура } \\
\text { пористості } \\
\text { м’якушки }\end{array}$ & \begin{tabular}{|c|} 
Серед- \\
ня, \\
нерівно- \\
мірна, \\
тонко- \\
стінна
\end{tabular} & $\begin{array}{r}\mathrm{Kp} \\
\text { нерів } \\
\text { товс }\end{array}$ & $\begin{array}{l}\text { пна, } \\
\text { омірна, } \\
\text { стінна }\end{array}$ & $\begin{array}{c}\text { Крупна, } \\
\text { нерівно- } \\
\text { мірна, } \\
\text { товсто- } \\
\text { стінна }\end{array}$ & $\begin{array}{r}\text { Cеу } \\
\text { нерів } \\
\text { тонк }\end{array}$ & $\begin{array}{l}\text { ня, } \\
\text { пірна, } \\
\text { iнна }\end{array}$ & $\begin{array}{c}\text { Середня, } \\
\text { нерівно- } \\
\text { мірна, } \\
\text { тонко- } \\
\text { стінна }\end{array}$ & $\begin{array}{r}\text { Дріс } \\
\text { рівно } \\
\text { тонко }\end{array}$ & $\begin{array}{l}\text { на, } \\
\text { рна, } \\
\text { iнна }\end{array}$ \\
\hline Смак & \multicolumn{9}{|c|}{ Приємний, з незначним присмаком кукурудзи } \\
\hline Запах & \multicolumn{9}{|c|}{ Приємний, властивий даному виду виробів } \\
\hline
\end{tabular}

У подальших дослідженнях визначали вплив сумісного внесення гідроколоїдів на показники якості безглютенового хліба. Готували суміші «ксантан : КМЦ» та «ксантан : ГПМЦ» у співвідношенні 0,5:1; 1:1 та 1:0,5.

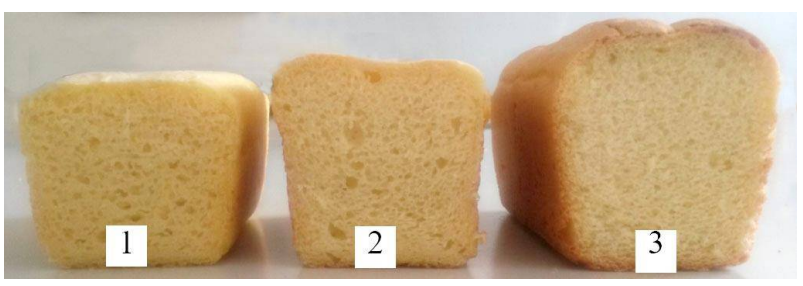

Рис. 1. Хліб із суміші рисового і кукурудзяного борошна 3 внесенням 0,5 \% структуроутворювачів:

1 - камедь ксантану, 2 - ГПМЦ, 3 - камедь ксантану і ГПМЦ у співвідношенні 0,5:1

Під час серії пробних випікань встановлено, що вироби із сумісним внесенням ксантану і похідних целюлози у співвідношенні 0,5:1 і 1:1 мають добре розвинену, тонкостінну пористість м’якушки, а також більший об'єм, ніж вироби з одним із видів структуроутворювачів (рис. 1). 
Найкращу якість за показниками, наведеними в табл. 1, мають вироби 3 сумішшю «ксантан:ГПМЦ» у співвідношенні $0,5: 1$. При чому чим більше додається цієї композиції структуроутворювачів, тим вищі значення питомого об'єму та показника пористості (рис. 2).

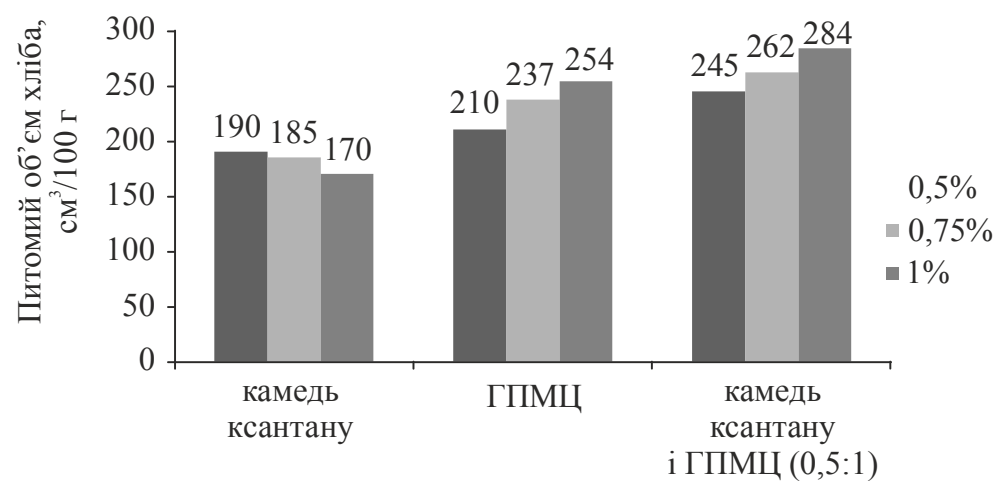

Рис. 2. Вплив структуроутворювачів на об’'м хліба

Вищезазначену композицію структуроутворювачів доцільно дозувати в кількості до 1,5\% до маси борошна. Збільшення дозування призводить до появи кристалічного блиску на поверхні виробів і неприємного післясмаку.

\section{Висновки}

Отже, результати досліджень показали, що для виготовлення безглютенового хліба з суміші рисового та кукурудзяного борошна доцільно використовувати комбінацію структуроутворювачів ксантан : ГПМЦ у співвідношенні 0,5:1 в кількості $1-1,5 \%$ до маси борошна. Це забезпечує одержання виробів 3 гарним об'ємом, гладкою поверхнею, добре розвинутою, рівномірною та тонкостінною структурою пористості м'якушки.

Подальші дослідження мають бути спрямовані на пошук технологічних заходів щодо покращення смаку й аромату виробів, подовження тривалості збереження ними свіжості.

\section{Лiтeратура}

1. Наумова О.А. Особенности питания больных целиакией / О.А. Наумова // Сучасні медичні технології. - 2010. — № 2. — С. 124-127.

2. Yolanda S. Effects of a gluten-free diet on gut microbiota and immune function in healthy adult humans / S. Yolanda // Gut Microbes. — 2010. — V. 1(3) - P. 135-137 [Електронний pecypc]. — Режим доступу : http://www.tandfonline.com/doi/abs/10.4161/gmic.1.3.11868.

3. Perlmutter $D$. Grain brain : the surprising truth about wheat, carbs, and sugar - your brain's silent killers / D. Perlmutter, K. Loberg. — London, Hodder \& Stoughton, 2014. — 323 p.

4. Gluten-free diet reduces adiposity, inflammation and insulin resistance associated with the induction of PPAR-alpha and PPAR-gamma expression. / F.L. Soares, R. de Oliveira Matoso, L.G. Teixeira et al. // J. Nutr. Biochem. — 2013. — Vol. 24(6). — P. 1105-1111.

5. Gluten-free diet [Електронний ресурс]. - Режим доступу : http : // www.mayoclinic.org/healthy-lifestyle/nutrition-and-healthy-eating/in-depth/gluten-free-diet.

6. Шаніна О.М. Обгрунтування складу борошняної сировини в технології безглютенового бездріжджового хліба / О.М. Шаніна, І.В. Галясний, Н.Л. Лобачова // East European 
Scientific Journal. — № 4, 2015. - С. 56-60 [Електронний ресурс]. - Режим доступу : http://eesa-journal.com/wp-content/uploads/2017/01/EESJ_4_21.pdf.

7. Патент 86050 Україна, МПК A21D 10/00 (2006.01). Спосіб виробництва безглютенового хліба / Шаніна О.М., Лобачова Н.Л., Гавриш Т.В.; заявник та патентовласник Харківський національного технічного університету сільського господарства Ім. П. Василенка. — № u201307689; заявл. 17.06.2013 р.; опубл.10.12.2013.; Бюл. № 23, 2013 p.

8. Semenova A. Gluten-free bakery products / A. Semenova, Ju. Prikhodko // 8th Central European Congress on Food 2016 — Food Science for Well-being (CEFood 2016), 23 - 26 May 2016 p. : Book of Abstracts. — Kyiv : NUFT, 2016. - P. 146.

9. Грищенко А.М. Удосконалення технології хліба з безглютенової сировини : автореф. дис. ... канд. техн. наук : 05.18.01 / Грищенко Анна Миколаївна. — Київ. - НУХТ, 2011. - $20 \mathrm{c}$.

10. Sabanis D. Effect of dietary fiber enrichment on selected properties of gluten-free bread / D. Sabanis, D. Lebesi and C. Tzia // LWT - Food Science and Technology. - October 2009. - Volume 42. - Issue 8. - P. 1380-1389.

11. Кучерук E.C. Влияние ксантановой камеди на свойства «муки безбелковой» / З.И. Кучерук, Е С. Цуканова // Scientific Letters of Academic Society of Michal Baludansky. — 2014. № 2(5). - C. 51-53.

12. Lazaridou A. Effects of hydrocolloids on dough rheology and bread quality parameters in gluten-free formulations / A. Lazaridou, D. Duta, M. Papageorgiou, N. Belc, C.G. Biliaderis // Journal of Food Engineering. — 2007. — Vol. 79(3). — P. 1033-1047. 